\title{
Crystals and skulls at Villa Gyllenberg
}

DOI: https://doi.org/ 10.30664/ar.101486

(c)(Attribution 4.0 International (CC BY 4.0)

The Path to Hidden Knowledge, art exhibition curated by Nina Kokkinen, 3.6.11.10.2020 at Villa Gyllenberg, Helsinki.

In light of Villa Gyllenberg's past history of presenting quite a traditional and conservative repertoire, the exhibition The Path to Hidden Knowledge in the summer and autumn of 2020 was out of the ordinary and surprising: crystals hung from the ceiling, an illuminated rose window was laid out on the floor and new-age music flowed by in the background. The museum's architecture was modified to create oriental doorways and dark, mirrored rooms.

Curated by Nina Kokkinen, an art historian and post-doctoral researcher in the study of religion, the exhibition focused on how Finnish art between 1890 and 1950 was influenced by esoteric ideas originating from many sources, ranging from Rosicrucianism to Anthroposophy, Theosophy, and Freemasonry. The theme of the exhibition, as well as the artists and works included in it, can be explored in more depth in the book Spiritual Treasures:

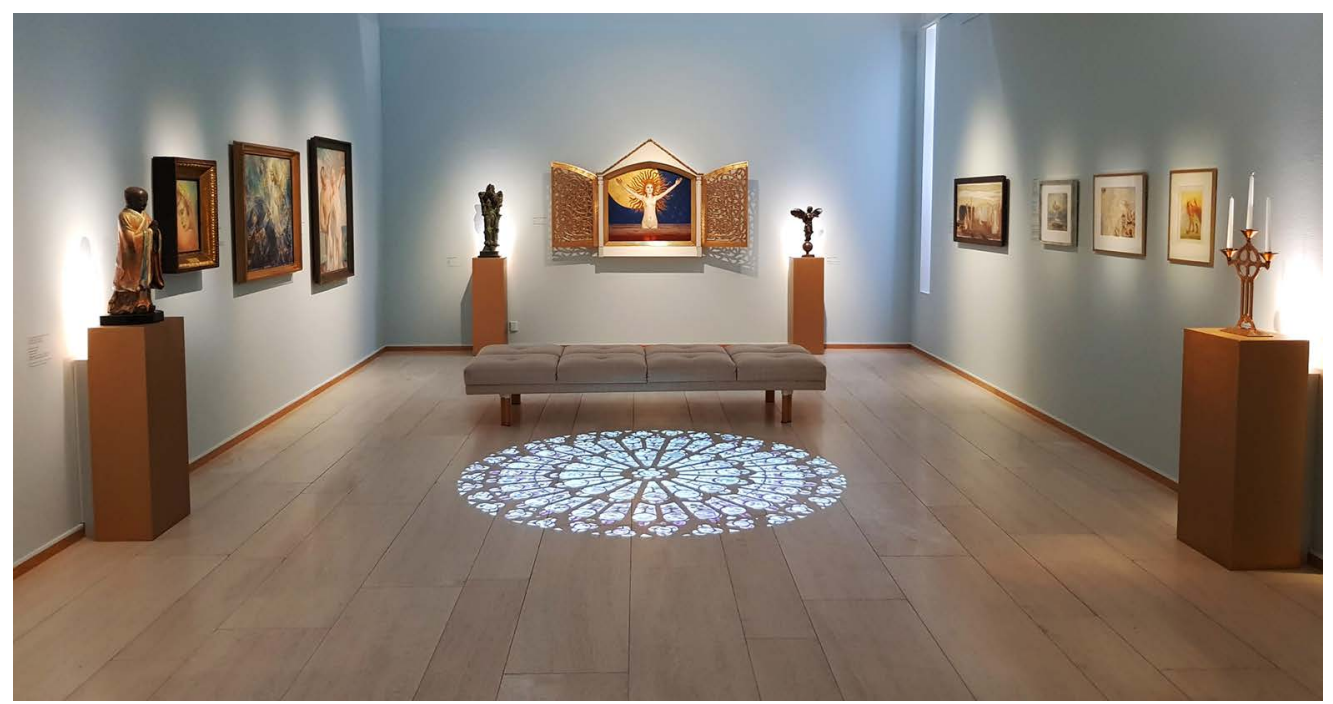

View from the exhibition The Path to Hidden Knowledge at Villa Gyllenberg in Helsinki.

Photo: Nina Kokkinen. 


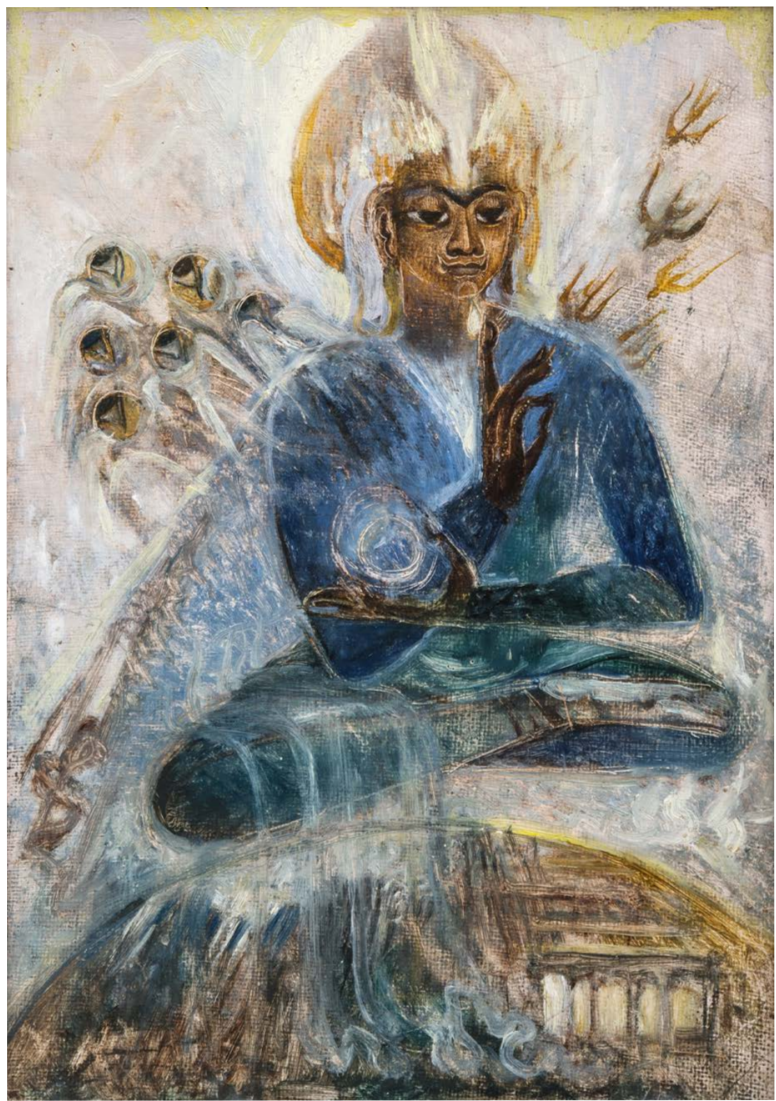

Ilona Harima, The Distant Message, 1930, oil on canvas, 25 x 18,5 cm, Villa Gyllenberg. Signe and Ane Gyllenberg Foundation.

Esotericism in the Finnish Art World 18901950 (eds. Nina Kokkinen and Lotta Nylund), published in connection with the exhibition. In the exhibition famous art-historical works were interspersed with those from relatively unknown names, as well as items such as altars, candlesticks and skulls. This exhibition brought to light the fact that though researchers have been interested in esotericism in art for a long time, the Finnish art scene has not been very much explored through those lenses. This exhibition was therefore important in the way it deepened and broadened the wider audience's view of twentieth-century art. And it is indeed timely, particularly in view of the latest ground-breaking exhibitions around the world of the work of Hilma af
Klint. Spirituality, self-understanding and higher knowledge are actually also the leitmotifs for the museum, a path laid out by its founder Ane Gyllenberg, the banker and art collector whose worldview was intimately bound up with Anthroposophy and Freemasonry.

The exhibition offered glimpses of established artists such as Akseli GallenKallela, Hugo Simberg, Ellen Thesleff and Helene Schjerfbeck, who were all interested in esotericism in one way or another. Many of them were never actual members of any movement, but rather seekers after truth who combined in their works spiritual impressions from a variety of sources. However, the exhibition also included works by relatively unknown artists, such as Ilona Harima, Meri Genetz and Werner von Hausen. Harima was familiar with the Theosophical worldview and in a work she produced in the 1930s, The Distant Message (Kaukainen viesti / Fjärran budskap), she puts forward the idea of progressive reincarnation. This small painting depicts an Oriental god figure holding a planet in his hand. Birds are flying towards it, like golden souls. To the left of the god figure, the souls have transformed into eyes. This transformation refers to the knowledge, skills and higher wisdom that the souls have attained during their bodily lives on the planet. Torsten Wasastjerna's large triptych When Nature Sleeps, the Spirit Watches (Kun luonto nukkuu, henki valvoo / När naturen sover, vakar anden, 1898) had not been displayed in its entirety for 120 years, and one can only wonder why. The symbolist landscape in the centre is surrounded by two angels at the sides - one with its sword pointing up, the other down. The angel paintings were found during the curation process in the temple of the Finnish Rosicrucian Society (Ruusu-Risti ry), founded by the Theosophist Pekka Ervast. 


\section{Gazed at by portraits}

Instead of focusing on art history, the curator of this exhibition had a more playful intention involving initiatory experience, and the presentation worked as a kind of 'handbook for spiritual seekers'. For example, black footprints on the floor directed visitors through the exhibition, and the idea of the seeker was heightened by Hugo Simberg's small but powerful The Stream of Life (1896). A great variety of styles were in evidence. The exhibition explored the theme of initiation in detail and sought different approaches to it. For example, Gallen-Kallela claimed in his writings that art has its origins in the human need to find a form for the divine mysteries of life and death. As a whole the exhibition made me see how the function of art itself can also be thought of as an initiation: art is meant to give its creator or viewer access to the kind of knowledge, emotions and experiences which they would not otherwise have been able to find. In this way, ideas about initiation are intertwined with artistic work and how it is received.

The question 'Who am I?' set its imprint on the entire first room: it was full of portraits and large mirrors that made the visitor feel they were being observed from all sides. Emil Halonen's nearly two-metretall aspen wood Christ figure formed a kind of centrepiece. Emil Halonen was a member of the Finnish Rosicrucian Society and this sculpture was borrowed from the society. It is usually installed as a centerpiece in their temple. In an intriguing portrait by the Anthroposophist Eva TörnwallCollin, a cigarette-smoking Rabbe Enckell regards himself in a mirror where he has a devil's face. There were also three highly passionate portraits by Meri Genetz, who was very interested in, for example, Theosophy, Kabbalah and Spiritualism. The broad selection of portraits - and especially

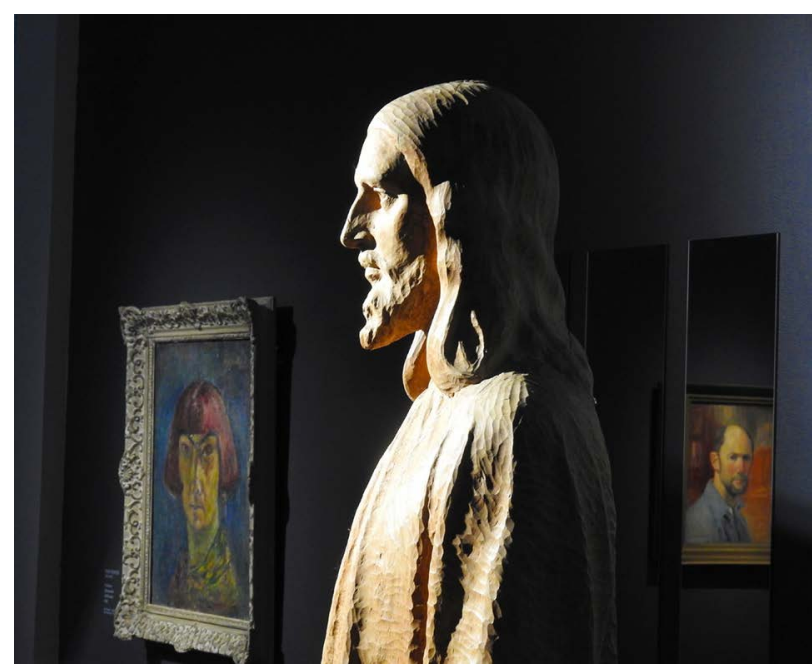

View from the exhibition. In the foreground Eemil Halonen's Christ, 1918, aspen, $45 \times 45 \times 185 \mathrm{~cm}$. Finnish Rosicrucian Society (Ruusu-Risti ry). Photo: Gabriella Tjeder-Kajander.

self-portraits - showed that Finnish artists were influenced by the tendency to ponder on the deep mysteries of life which was very common in Paris in the early 1890 . Questions like 'What am I and where have I come from; where am I going and what am I going to do?' were all intrinsically linked to esotericism. Beda Stjernschantz's Aphorism (1895) is also clearly related to reflections on human existence, portraying a young boy dressed in a black robe typical of initiated masters and truth-seekers. At the bottom one can read Descartes's cogito, ergo sum ('I think, therefore I am'). The boy's eye cannot be caught since he is focusing on his own inner world. In addition to this his hands are gesturing the figure eight, suggesting eternity. Their position also closely resembles the Dharmachakra mudra oriental hand gesture, which is common not only in representations of the Buddha but also of many other masters from India and Tibet. In fin-de-siècle occulture, the Buddha was regarded as one of the most important masters of hidden knowledge. Stjernschantz's painting suggests 
that the same knowledge can be reached through introspection and exploration of the inner world of the self.

\section{Death in focus}

The memento mori and the symbolist figure of death were key themes in the blacktoned middle room of Villa Gyllenberg, where muted church bells dramatically played softly in the background. Symbolic death often represents one stage in esoteric initiation and the path it offers to spiritual development. This room was filled with a mixture of paintings depicting memento mori themes such as skulls, watches and hourglasses, and candles. The back wall was totally taken up by Oscar Parviainen's large painting, the Crypt of the Capuchin Friars (Kapusiinimunkkien hautakammios$s a, 1914)$, stocked full of skulls. Next to it stood a table arrangement with a masonic candlestick, an hourglass and a skull from Akseli Gallen-Kallela's collection; there was also a painting of his, River of the Dead (Kuolleitten virta / De dödas flod, 1893), and pictures of a peasant and Death by Hugo Simberg. There were rather shocking revelations for me, such as how GallenKallela would be so extreme in his creative process that he occasionally would lie down in a newly-dug grave after his afternoon coffee, when he was doing frescos for the Jusélius Mausoleum at a cemetery in Pori! He claimed he drew creative power from the earth of the dead and was able to feel the force and energy of the world soul. He also wore a monk's habit, and in 1897 his student Hugo Simberg had, in Italy, contemplated living as a monk devoted to art. In a throwback to romanticism, both artists perceived nature as endowed with soul and full of life.

\section{Rose window under your feet}

The last room in the exhibition was bright and filled with soft, abstract sounds, like

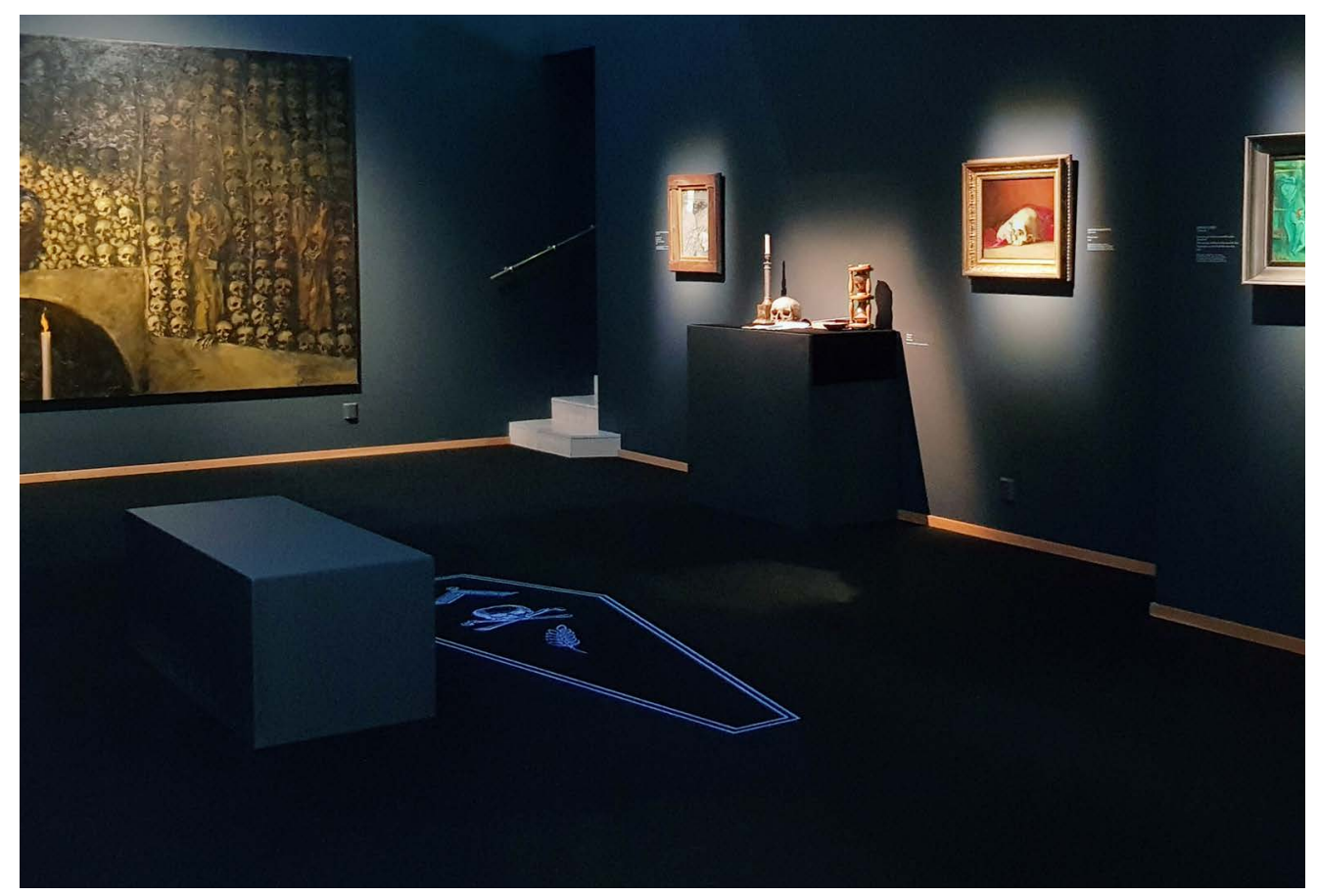

View from the exhibition The Path to Hidden Knowledge at Villa Gyllenberg in Helsinki.

Photo: Nina Kokkinen. 


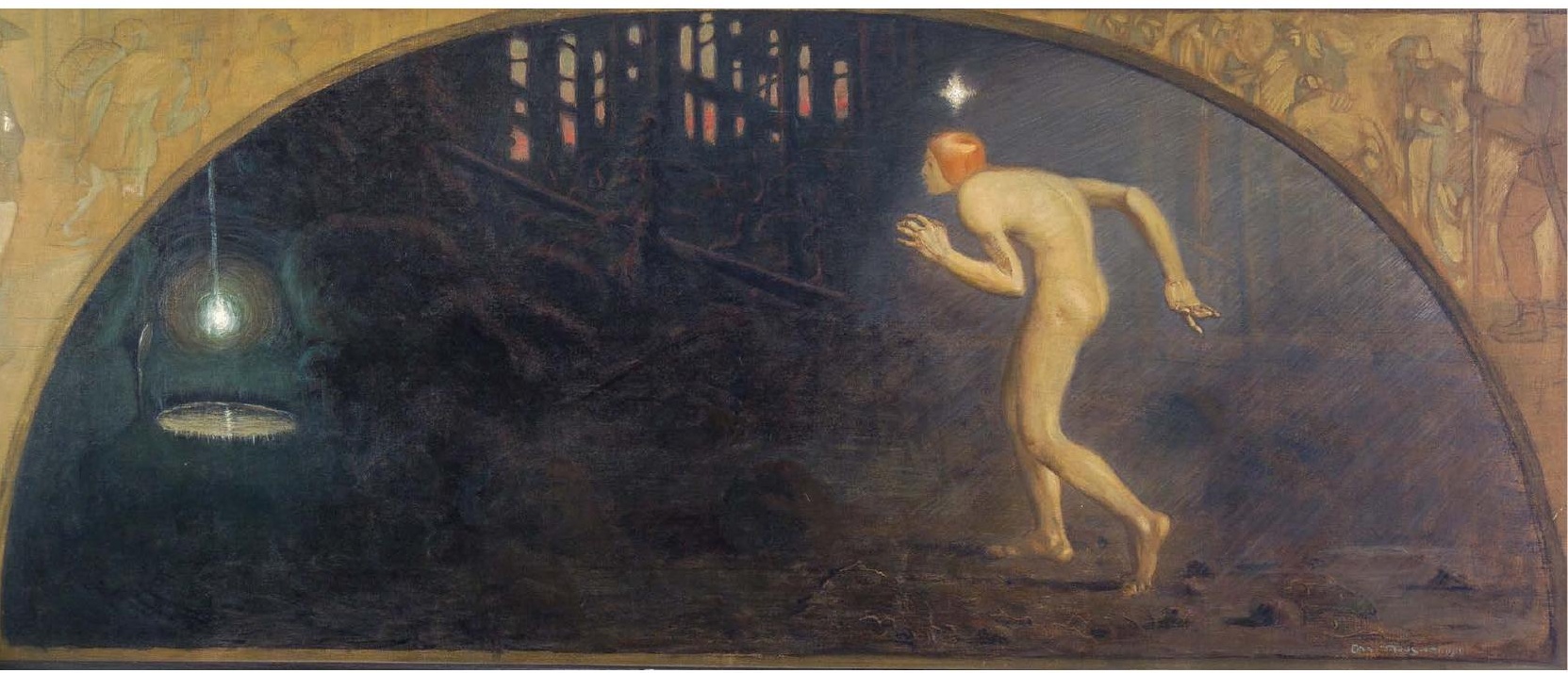

Onni Muusari, The Treasure Hunter, 1910, oil on canvas, glued on cardboard, $62 \times 150 \mathrm{~cm}$, Villa Gyllenberg. Signe and Ane Gyllenberg Foundation.

glitter. The mise en scène seems like a path to redemption, and the question that came to me was 'Who are we?', in the sense that we all come from the same light. On the floor, like a carpet, was a glowing rose window and the entrance to the space was oriental in shape. An eighteenth-century statue of the Buddha was accompanied by a Rosicrucian candlestick and Eva TörnwallCollin's picture of eurythmy. Next to it was Ellen Thesleff's abstract Angel with Trombone (Pasuunaenkeli / Basunängeln, 1925) and Sakari Tohka's bronze angel (1939). Thesleff's delicate, ethereal style differs markedly from Tohka's masculine idiom. Overall, the room featured many pictures of angels, which appear as guides to spiritual wisdom. Akseli Gallen-Kallela's large Ad Astra (1907) functioned as a kind of terminus, altar, or focus point. In the painting the red hair of the maiden, ascending into the celestial spheres, shimmers magnetically, and her eyes evoke a state of clairvoyance. Behind the maiden shines a golden planet: her future. The maiden's pose suggests not only the Christian resur- rection, but also the crucifixion which is underlined by the stigmata. Therefore, the Christian theme of the resurrection intertwines with the idea of progressive reincarnation, which became common during the nineteenth century with the spread of Theosophical ideas, for example. This famous painting is usually part of the Gyllenberg Collection and it appeared very differently in this setting, more clearly denoting the rebirth of the soul.

\section{The sphinx and the hexagram}

What, then, are the criteria for a work to be identified as belonging to esoterica? The whole question can appear rather woolly, considering that this was the period of Symbolism and that much of Modernism demonstrates a kind of quest for truth. One entire wall in the exhibition was dedicated to Helene Schjerfbeck's paintings - rather surprising, one might think, and yet prominent spiritual features are identifiable in a painting of a female profile surrounded by scratched gold, like a halo, showing how Schjerfbeck delved into the spiritual on a 
highly individual plane. In general, spiritualist teachings and secret séances offered women artists the opportunity to experiment more freely than was otherwise culturally acceptable at the time. I would have liked to see more of such experimental works in the exhibition, such as examples of automatic drawing.

By contrast to Schjerfbeck's Expressionism, masonic symbols are quite clear, and Anthroposophical imagery has a distinctive framework in its hazy and pastel expression. Recurring symbols in the exhibition included the hexagram and the sphinx, as well as seekers and wanderers in search of the light, such as Onni Muusari's The Treasure Hunter (Aarteenetsijä / Skattsökaren, 1910). In this large painting, a naked young man cautiously approaches a glowing light in the dark forest. It is all set in a fairy-tale-like atmosphere. Artists in general during this time were considered to have a special talent for clairvoyance and were frequently called prophets or magicians. Artists often depicted themselves as pilgrims, clad in a robe and with a wanderer's staff in their hand. Muusari's truth-seeker is depicted naked, without a robe or cloak, more like a mythical sphinx. The nakedness of the seeker underlines his authenticity, sincerity and the purity of his intentions. The painting shows that this truth-seeker has, after a long journey, finally found his treasure, the source of light and higher wisdom. The same source of enlightenment also shines above the young man's head.

\section{The longing for an answer}

Should, then, the artists in the exhibition be seen as artists or as mediums? Some of the featured artworks seem like maps of a spiritual endeavour, but also like expressions of a tumultuous period that felt a need for this kind of spirituality. As a whole, the exhib- ition neither prophesied nor lectured. It functioned as a mixture of elements associated with esoteric spirituality, and it offered a view into, and a new interpretation of, the history of art, but also raised intriguing questions about why the theme is still of interest at this specific point in time. In an age of rational thinking, industrialisation and urbanisation, artists embarked on a quest for a deeper truth - issues that are topical even today. I can assume that some Gallen-Kallela enthusiasts may be offended by the discovery of this esoteric side of our national artist. Esotericism has been given a negative label because it has been associated, for example, with Nazis, hippies, and drug-taking. In this respect, the exhibition functioned as a platform for discussion. It raised questions about how we see life today and how the history of art is written. It left me with the notion that if we have the understanding and the sense to appreciate human beings striving for the beauty embodied in art, then can we not also appreciate human questions and the need for answers? I hope to see more exhibitions of this kind in Villa Gyllenberg. It would also be rewarding to explore the esoteric in abstract and contemporary Finnish art, even if little research has been done in this area.

\section{Camilla Granbacka}

Camilla Granbacka is an art historian specialising in contemporary art and modernism. She is currently working as a curator at the Pro Artibus Foundation. She has worked as an art critic for Hufvudstadsbladet and also for Dagens Nyheter and konsten.net.

\section{Reference}

Kokkinen, Nina, 2020. 'Initiation in art and esotericism', in Spiritual Treasures: Esotericism in the Finnish Art World 1890-1950, eds. Nina Kokkinen and Lotta Nylund (Helsinki: Parvs), 8-23. 